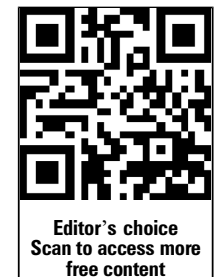

free content
- Additional material is published online only. To view please visit the journal online (http://dx.doi.org/10.1136/ sextrans-2013-051456).

${ }^{1}$ Virus, Lifestyle and Genes, Danish Cancer Society Research Center, Copenhagen, Denmark

${ }^{2}$ Statistics, Bioinformatics and Registry, Danish Cancer Society Research Center, Copenhagen, Denmark

${ }^{3}$ Gynecologic Clinic, Rigshospitalet, University of Copenhagen, Copenhagen, Denmark

\section{Correspondence to} Professor Susanne Krüger Kjaer, Virus, Lifestyle and Genes, Danish Cancer Society Research Center, Strandboulevarden 49 , Copenhagen $\varnothing$ DK-2100, Denmark; susanne@cancer.dk

Received 20 November 2013 Revised 20 March 2014 Accepted 9 April 2014 Published Online First 8 May 2014

\title{
Human papillomavirus prevalence among men in sub-Saharan Africa: a systematic review and meta-analysis
}

\author{
Tina Bech Olesen, ${ }^{1}$ Christian Munk, ${ }^{1}$ Jane Christensen, ${ }^{2}$ Klaus Kaae Andersen, ${ }^{2}$ \\ Susanne K Kjaer ${ }^{1,3}$
}

\section{ABSTRACT}

Background We performed a systematic review and meta-analysis to summarise the available data on the prevalence of human papillomavirus (HPV) among men in sub-Saharan Africa.

Methods PubMed and Embase were searched up to 10 March 2014. Random effects meta-analyses were used to calculate a pooled prevalence of any HPV and high-risk (HR) HPV.

Results A total of 11 studies comprising 9342 men were identified. We found that HPV is very common among men in sub-Saharan Africa, the prevalence of any HPV ranging between $19.1 \%$ and $100 \%$. Using random effects meta-analysis, the pooled prevalence of any HPV was $78.2 \%(95 \% \mathrm{Cl} 54.2$ to 91.6$)$ among HIV-positive and $49.4 \%(95 \% \mathrm{Cl} 30.4$ to 68.6$)$ among HIV-negative men $(p=0.0632)$. When restricting the analyses to PCRbased studies, the pooled prevalence of any HPV was $84.5 \%(95 \% \mathrm{Cl} 74.2$ to 91.2$)$ among HIV-positive and $56.4 \%(95 \% \mathrm{Cl} 49.7$ to 62.9$)$ among HIV-negative men $(p<0.0001)$. Of the HPV types included in the ninevalent HPV vaccine, the most common HR HPV types were HPV 16 and HPV52, and HPV6 was the most common low-risk HPV type. When examining the prevalence of HPV in relation to age no clear trend was observed.

Conclusions The prevalence of HPV is high among men in sub-Saharan Africa, which could contribute to the high rates of penile and cervical cancer in this part of the world. Implementation of the prophylactic HPV vaccines could potentially help prevent this large burden of HPV and HPV-associated disease in sub-Saharan Africa.

ClinicalTrials.gov identifier: NCT00932009.

\section{INTRODUCTION}

Human papillomavirus (HPV) is the most common sexually transmitted infection. HPV is associated with cervical cancer in women, though it is increasingly recognised that HPV causes a substantial disease burden in men also, including genital warts, penile cancer, anal cancer and head-and-neck cancer. ${ }^{1}$ The prevalence of HPV and the burden of HPV-related cancers vary across populations. In sub-Saharan Africa, the rates of penile and cervical cancer are among the highest worldwide, ${ }^{2}$ which is possibly related to the high prevalence of both HPV and HIV, and also to the lack of effective screening programmes.

More than 120 types of HPV exist and these are divided into high-risk (HR) and low-risk (LR) types depending on their oncogenic potential. ${ }^{3}$ HPV16 and HPV18 are the most important HR HPV types accounting for the largest numbers of HPV-related cancers worldwide: HPV16 and HPV18 are the most common HPV types in penile cancer and cervical cancer ${ }^{4} 5$ and, furthermore, HPV16 is the most common HR HPV type detected in head-and-neck cancer. ${ }^{6}$ Two prophylactic vaccines against HPV have been developed: the quadrivalent HPV vaccine targeting HPV6/11/16/18 and the bivalent targeting HPV16/18. Furthermore, a ninevalent $H P V$ vaccine targeting HPV6/11/16/18/31/ $33 / 45 / 52 / 58$ is currently under development. The quadrivalent HPV vaccine has been shown to prevent HPV infection in men and to be highly immunogenic in HIV-positive men. ${ }^{7}$

The large burden of HPV-related disease in sub-Saharan Africa underlines the importance of estimating the HPV prevalence in this region. Furthermore, this will increase the understanding of the natural history of HPV across populations. Previous reviews of HPV prevalence among men included only three studies or fewer from sub-Saharan Africa. ${ }^{8}{ }^{9}$ We performed a systematic review and meta-analysis to summarise the available data on the overall, type-specific and age-specific prevalence of genital HPV DNA among men in sub-Saharan Africa.

\section{MATERIAL AND METHODS}

Search strategy

The study was conducted in accordance with the PRISMA guidelines. ${ }^{10}$ We searched PubMed and Embase up to 10 March 2014 using search terms (MeSH terms or subject headings, and free text) for HPV, prevalence, men and countries in sub-Saharan Africa (see online supplementary appendix A). The searches were restricted to English language publications. There were no publication date restrictions. We identified 120 records in PubMed and 50 records in Embase; in total 170 records (see online supplementary figure S1). After removal of duplicates $(n=43)$, all abstracts $(n=127)$ were reviewed independently by two authors (TBO and $\mathrm{CM}$ ). Altogether 85 papers were excluded based on abstract reviews. Full-text copies of potentially relevant papers $(n=42)$ were obtained and reviewed independently by two authors (TBO and $\mathrm{CM}$ ). Furthermore, reference lists of all full-texts articles were searched, although this did not result in any additional papers. Any inconsistencies in the identification of potentially relevant papers were discussed to reach consensus. Of these 42 papers, 31 were excluded based on the full-text. 


\section{Eligibility criteria}

Studies reporting genital HPV DNA prevalence among study populations including more than 20 men in sub-Saharan Africa were eligible. Eligible samples included scrape or swab specimens from the male genital area including the urethra, glans, shaft, scrotum and perineum. Studies were restricted to those detecting HPV DNA using PCR-based methods or non-PCR-based methods (eg, Hybrid Capture 2) because of the lower sensitivity and specificity of other DNA detection methods. $^{11}$

\section{Data extraction}

For each study we extracted the following information: first author and year of publication; country; year of study; description of study population; presence of symptoms; sample size; age (mean/median/range); anatomical site for specimen collection; circumcision status; HIV status; HPV DNA detection method; prevalence of any HPV and/or HR HPV; type-specific prevalence of the HPV types included in the nine-valent HPV vaccine (HPV6/11/16/18/31/33/45/52/58); and age-specific prevalence of any and/or HR HPV when available. Presence of symptoms was defined as studies where the majority of the men had symptoms of HPV infection (presence of genital warts or men attending an STD clinic). When published results were presented only graphically, prevalence was read off from these graphical representations (in two studies). ${ }^{12}{ }^{13}$ Study populations described in more than one paper were included only once and data from the paper with the most detailed information were used. Studies were grouped into subregions of sub-Saharan Africa (eastern Africa, middle Africa, southern Africa and western Africa) as defined by the United Nations geoscheme for Africa. ${ }^{14}$

\section{Statistical analysis}

For each study, the overall prevalence of any HPV and HR HPV, the prevalence of any HPV and HR HPV in relation to circumcision status and the type-specific prevalence of HPV6/11/16/18/ $31 / 33 / 45 / 52 / 58$ were tabulated. The prevalence of any HPV and HR HPV in relation to HIV status and the age-specific prevalence of any and/or HR HPV and 95\% CIs was displayed graphically.

The pooled prevalence of any HPV and/or HR HPV and 95\% CIs was estimated using the DerSimonian and Laird random effects method for meta-analysis ${ }^{15}$ in relation to the a priori defined study-level variables: HPV DNA detection method (PCR, non-PCR), anatomical site for specimen collection (urethra only, other penile sites) and presence of symptoms (yes, no).

The pooled prevalence of any and/or HR HPV in relation to the a priori defined individual-level variables HIV status (HIV-negative, HIV-positive) and circumcision status (circumcised, uncircumcised) was estimated using random effects meta-analysis of single proportions by applying the Freeman-Tukey Double arcsine transformation and the DerSimonian-Laird estimator to estimate the between-study variance. ${ }^{15}$ In these analyses, only studies that had data for each category of the variable (eg, HIV-positive and HIV-negative) were included. Meta-regression was performed and the univariable models were evaluated from the $\mathrm{p}$ value for the test of moderators.

For the above analyses, between-study heterogeneity was evaluated using $\mathrm{I}^{2}$ and the $\mathrm{p}$ value for heterogeneity (Cochrane's $\mathrm{Q}$ statistic). ${ }^{16}$
Data were analysed using the statistical software STATA V.11.2 (StataCorp, Texas) and R V.3.0.1 and the package meta 2.4.1. ${ }^{17}$

\section{RESULTS}

\section{Description of studies}

From the systematic review, we identified 11 studies comprising 9342 men examining the prevalence of HPV DNA among men in sub-Saharan Africa. These studies included six cross-sectional studies $^{18-23}$ and five randomised controlled trials (RCTs) in

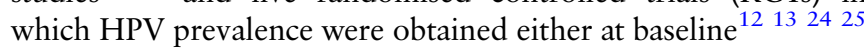
or at follow-up ${ }^{26}$ (table 1). All identified studies were from southern Africa $(n=6)$ or eastern Africa $(n=5)$. Altogether six studies were from South Africa, ${ }^{13} 1820212526$ two studies were conducted in Kenya ${ }^{12}{ }^{19}$ and three studies were from Rwanda, ${ }^{22}$ Tanzania $^{23}$ and Uganda, ${ }^{24}$ respectively. No studies from western Africa or middle Africa were identified. In the two RCTs of male circumcision from which baseline data were obtained, ${ }^{12}{ }^{24}$ all study participants were uncircumcised. In all other studies, the circumcision prevalence ranged from $7.2 \%$ to $96.6 \% .^{13} 19-2326$ The RCT of male circumcision conducted in Kenya ${ }^{12}$ included only HIV-negative men and one study from South Africa comprised only HIV-positive men. ${ }^{21}$ For the remaining studies, the prevalence of HIV ranged between $2 \%$ and $49.5 \% .^{13} \quad 18-2022-$ $24{ }^{26}$ In three studies, ${ }^{18} 2021$ the majority of men had symptoms of HPV infection: Müller et al included 214 sexual health clinic attendees of whom 108 had ano-genital warts, ${ }^{20}$ in the study by Firnhaber et al all men $(n=74)$ had penile warts ${ }^{21}$ and Vogt et al included 34 men attending an HIV testing centre. ${ }^{18}$ One study sampled exfoliated cells from the urethra only, ${ }^{26}$ while the remaining studies sampled other penile sites (eg, glans, coronal sulcus and shaft). ${ }^{12}{ }^{13}{ }^{18-25}$ For the detection of HPV DNA, 10 studies used PCR-based methods ${ }^{12} 1^{13} \quad 18-22 \quad 24-26$ and one study used a non-PCR-based method (Hybrid Capture 2) ${ }^{23}$ (table 1).

\section{Prevalence of HPV}

In table 1 the prevalence of any HPV and HR HPV for each study is shown. Among the 11 studies identified, nine presented data on the prevalence of any HPV and seven studies had data on HR HPV. The prevalence of any HPV ranged from 19.1\% (95\% CI 17.2 to 21.0$)^{26}$ to $100 \%$ (95\% CI 85.3 to 100.0$)^{21}$ and the prevalence of HR HPV from $16.2 \%$ (95\% CI 14.5 to $17.9)^{23}$ to $84.9 \%(95 \%$ CI 76.7 to 93.1$) .^{21}$ The lowest HPV prevalence was seen in the study by Auvert et al sampling the urethra only ${ }^{26}$ and in the study by Olesen et al using a nonPCR-based method. ${ }^{23}$ The highest HPV prevalence was observed among HIV-positive men. ${ }^{21}$

In PCR-based studies, the pooled prevalence was $61.1 \%$ (95\% CI 44.1 to 78.1 ) for any HPV and $41.6 \%$ (95\% CI 23.3 to 60.0) for HR HPV using random effects meta-analysis. Among men with symptoms of HPV infection, the pooled prevalence of any HPV was $79.0 \%$ (95\% CI 60.8 to 97.3 ) and $46.0 \%$ (95\% CI 27.7 to 64.3) among asymptomatic men $(\mathrm{p}=0.0425)$. In studies sampling other penile sites (eg, glans, coronal sulcus and shaft), the pooled prevalence of any HPV was $61.3 \%$ (95\% CI 44.7 to 77.8 ) (data not shown).

In all studies, the prevalence of any HPV and HR HPV was higher among HIV-positive men than among HIV-negative men (figure 1 and online supplementary table S1). Using random effects meta-analysis, the pooled prevalence of any HPV was 78.2\% (95\% CI 54.2 to 91.6) among HIV-positive and $49.4 \%$ (95\% CI 30.4 to 68.6$)$ among HIV-negative men $(p=0.0632)$. The pooled HR HPV prevalence was 58.6\% (95\% CI 21.0 to 91.0) among HIV-positive and 25.0\% (95\% CI 10.5 to 43.2 ) among HIV-negative men $(\mathrm{p}=0.0503)$. In PCR-based studies, 
Table 1 Description of studies reporting HPV prevalence among men in sub-Saharan Africa

\begin{tabular}{|c|c|c|c|c|c|c|c|c|c|c|c|}
\hline Authors & $\begin{array}{l}\text { Country and year } \\
\text { of study }\end{array}$ & Study design & $\begin{array}{l}\text { Study population } \\
\text { (symptoms yes/no)* }\end{array}$ & $\begin{array}{l}\text { Study size } \\
\text { (N) }\end{array}$ & Age (years) & Anatomical site & $\begin{array}{l}\mathrm{n} / \mathrm{N}(\%) \\
\text { circumcised }\end{array}$ & $\begin{array}{l}\mathrm{n} / \mathrm{N}(\%) \\
\text { HIV-positive }\end{array}$ & $\begin{array}{l}\text { HPV detection } \\
\text { method }\end{array}$ & $\begin{array}{l}\text { Prevalence of any } \\
\text { HPV } n / N(\%)\end{array}$ & $\begin{array}{l}\text { Prevalence of HR } \\
\text { HPV } n / N(\%)\end{array}$ \\
\hline $\mathrm{Ng}^{\prime}$ ayo et $a l^{19}$ & Kenya, 2005 & Cross-sectional & $\begin{array}{l}\text { Men working in the } \\
\text { fishing industry } \\
\text { (no symptoms) }\end{array}$ & 250 & $\begin{array}{l}\text { Mean 31.3 } \\
\text { (range 18-63) }\end{array}$ & $\begin{array}{l}\text { Glans, corona sulcus, } \\
\text { shaft, scrotum and the } \\
\text { perianal region }\end{array}$ & $18 / 250(7.2 \%)$ & $64 / 250(25.6 \%)$ & PCR (PGMY09/11) & $144 / 250(57.6 \%)$ & $106 / 250(42.2 \%)$ \\
\hline Auvert et $a l^{26}$ & $\begin{array}{l}\text { South Africa, } \\
\text { 2005-2006 }\end{array}$ & $\begin{array}{l}\text { 21-month } \\
\text { follow-up data } \\
\text { from RCT }\end{array}$ & $\begin{array}{l}\text { Men recruited from the } \\
\text { general population for an } \\
\text { RCT of male circumcision } \\
\text { (no symptoms) }\end{array}$ & 1683 & $\begin{array}{l}\text { Mean 20.7 } \\
\text { (median 21; } \\
\text { IQR=19-22) }\end{array}$ & Urethra & $\begin{array}{l}863 / 1683 \\
(51.3 \%)\end{array}$ & $33 / 1683(2.0 \%)$ & $\begin{array}{l}\text { PCR (Roche } \\
\text { Amplicor HPV test) }\end{array}$ & $321 / 1683(19.1 \%)$ & $291 / 1683(17.3 \%)$ \\
\hline $\begin{array}{l}\text { Mbulawa } \\
\text { et } a l^{13}\end{array}$ & $\begin{array}{l}\text { South Africa, } \\
\text { 2006-2007 }\end{array}$ & $\begin{array}{l}\text { Baseline data } \\
\text { from RCT }\end{array}$ & $\begin{array}{l}\text { Heterosexual men } \\
\text { recruited for } \\
\text { investigations of genital } \\
\text { HPV transmission } \\
\text { (no symptoms) }\end{array}$ & 486 & $\begin{array}{l}\text { Mean } 38 \\
\text { (range 19-67) }\end{array}$ & $\begin{array}{l}\text { Shaft and glans, and the } \\
\text { foreskin in uncircumcised } \\
\text { men }\end{array}$ & $451 / 467(96.6 \%)$ & 161/486 (33.1\%) & $\begin{array}{l}\text { PCR (Roche Linear } \\
\text { Array HPV } \\
\text { Genotyping test) }\end{array}$ & $273 / 471(58.0 \%)$ & NA \\
\hline Müller et $a l^{20}$ & $\begin{array}{l}\text { South Africa, } \\
2006-2008\end{array}$ & Cross-sectional & $\begin{array}{l}\text { Men attending a sexual } \\
\text { health clinic (symptoms) }\end{array}$ & 214 & $\begin{array}{l}\text { Mean } 29.8 \\
\text { (SD 7.50) }\end{array}$ & $\begin{array}{l}\text { Glans penis, coronal } \\
\text { sulcus, penile shaft and, } \\
\text { if present, anogenital } \\
\text { warts }\end{array}$ & $54 / 208(26.0 \%)$ & 104/210 (49.5\%) & $\begin{array}{l}\text { PCR (Roche Linear } \\
\text { Array HPV } \\
\text { Genotyping test) }\end{array}$ & $166 / 214(77.6 \%)$ & NA \\
\hline Smith et $a l^{12}$ & Kenya, 2002-2005 & $\begin{array}{l}\text { Baseline data } \\
\text { from RCT }\end{array}$ & $\begin{array}{l}\text { Men screened to } \\
\text { participate in an RCT of } \\
\text { male circumcision } \\
\text { (no symptoms) }\end{array}$ & 2705 & $\begin{array}{l}\text { Median } 20 \\
\text { (range 17-28) }\end{array}$ & $\begin{array}{l}\text { Shaft, glans, coronal } \\
\text { sulcus, and inner and } \\
\text { external foreskin tissue }\end{array}$ & $0 / 2705(0 \%)$ & $0 / 2705(0 \%)$ & PCR (GP5+/6+) & $1382 / 2705(51.1 \%)$ & NA \\
\hline $\begin{array}{l}\text { Firnhaber } \\
\text { et }\left.a\right|^{21}\end{array}$ & $\begin{array}{l}\text { South Africa, } \\
2007-2008\end{array}$ & Cross-sectional & $\begin{array}{l}\text { Men with penile warts } \\
\text { attending a public sector } \\
\text { antiretroviral treatment } \\
\text { clinic (symptoms) }\end{array}$ & 74 & $\begin{array}{l}\text { Mean } 36.0 \\
(S D \pm 6.6)\end{array}$ & $\begin{array}{l}\text { Prepuce, penile shaft and } \\
\text { genital wart areas of the } \\
\text { penis }\end{array}$ & $14 / 65(21.5 \%)$ & $74 / 74(100 \%)$ & $\begin{array}{l}\text { PCR (Roche Linear } \\
\text { Array HPV } \\
\text { Genotyping test) }\end{array}$ & $73 / 73(100.0 \%)$ & $62 / 73(84.9 \%)$ \\
\hline Vardas et $a l^{25} \dagger$ & $\begin{array}{l}\text { South Africa, } \\
\text { 2004-2008 }\end{array}$ & $\begin{array}{l}\text { Baseline data } \\
\text { from RCT }\end{array}$ & $\begin{array}{l}\text { Heterosexual men } \\
\text { participating in an HPV } \\
\text { vaccine trial } \\
\text { (no symptoms) }\end{array}$ & 518 & $\begin{array}{l}\text { Mean: NA } \\
\text { (range 16-24) }\end{array}$ & $\begin{array}{l}\text { Penile, scrotal, and } \\
\text { perineal/perianal areas }\end{array}$ & NA & NA & $\begin{array}{l}\text { PCR (Real-time } \\
\text { multiplex PCR) }\end{array}$ & NA & NA \\
\hline $\begin{array}{l}\text { Veldhuijzen } \\
\text { et } a^{22}\end{array}$ & $\begin{array}{l}\text { Rwanda, } \\
\text { 2007-2009 }\end{array}$ & Cross-sectional & $\begin{array}{l}\text { Men participating in a } \\
\text { case-control study } \\
\text { assessing risk factors for } \\
\text { infertility (no symptoms) }\end{array}$ & 166 & $\begin{array}{l}\text { Median 31 } \\
\text { (IQR 27-38) }\end{array}$ & $\begin{array}{l}\text { Shaft, scrotum, glans/ } \\
\text { sulcus corona, and } \\
\text { foreskin in uncircumcised } \\
\text { men }\end{array}$ & 38/166 (22.9) & $13 / 166(7.8 \%)$ & $\begin{array}{l}\text { PCR (Roche Linear } \\
\text { Array HPV } \\
\text { Genotyping test) }\end{array}$ & NA & $44 / 166(26.5 \%)$ \\
\hline Olesen et $a l^{23}$ & Tanzania, 2009 & Cross-sectional & $\begin{array}{l}\text { Men from the general } \\
\text { population } \\
\text { (no symptoms) }\end{array}$ & 1813 & $\begin{array}{l}\text { Mean 34.2 } \\
\text { (median 30) }\end{array}$ & $\begin{array}{l}\text { Glans, preputial cavity } \\
\text { (uncircumcised men), } \\
\text { coronal sulcus } \\
\text { (circumcised men), shaft, } \\
\text { corpus }\end{array}$ & $\begin{array}{l}1594 / 1809 \\
(88.1 \%)\end{array}$ & $140 / 1483(9.4 \%)$ & $\begin{array}{l}\text { Non-PCR (Hybrid } \\
\text { Capture 2) and } \\
\text { PCR (LiPAv2) for } \\
\text { genotyping }\end{array}$ & $372 / 1813(20.5 \%)$ & $294 / 1813(16.2 \%)$ \\
\hline Tobian et al ${ }^{24}$ & $\begin{array}{l}\text { Uganda, } \\
\text { 2003-2006 }\end{array}$ & $\begin{array}{l}\text { Baseline data } \\
\text { from RCT }\end{array}$ & $\begin{array}{l}\text { Men enrolled into two } \\
\text { RCTs of male } \\
\text { circumcision for HIV and } \\
\text { STI prevention } \\
\text { (no symptoms) }\end{array}$ & 1399 & $\begin{array}{l}\text { Mean: NA } \\
\text { (range 15-49) }\end{array}$ & Coronal sulcus and glans & 0/1399 (0\%) & 421/1399 (30.1\%) & PCR (PGMY09/11) & 978/1399 (69.9\%) & $690 / 1399(49.3 \%)$ \\
\hline Vogt et $a l^{18}$ & South Africa, 2011 & Cross-sectional & $\begin{array}{l}\text { Heterosexual men } \\
\text { attending an HIV testing } \\
\text { centre (symptoms) }\end{array}$ & 34 & $\begin{array}{l}\text { Median 33 } \\
\text { (IQR 29-37) }\end{array}$ & $\begin{array}{l}\text { Coronal sulcus, glans and } \\
\text { shaft }\end{array}$ & NA & $3 / 34(8.8 \%)$ & PCR (PGMY09/11) & $20 / 34(58.8 \%)$ & $10 / 34(29.4 \%)$ \\
\hline
\end{tabular}


Figure 1 Prevalence of any human papillomavirus (HPV) (A) and high-risk (HR) HPV (B) in relation to HIV status among men in sub-Saharan Africa*. *Please see online supplementary table $\mathrm{S} 1$ for the exact numbers used in the graph.

\section{A. Any HPV}

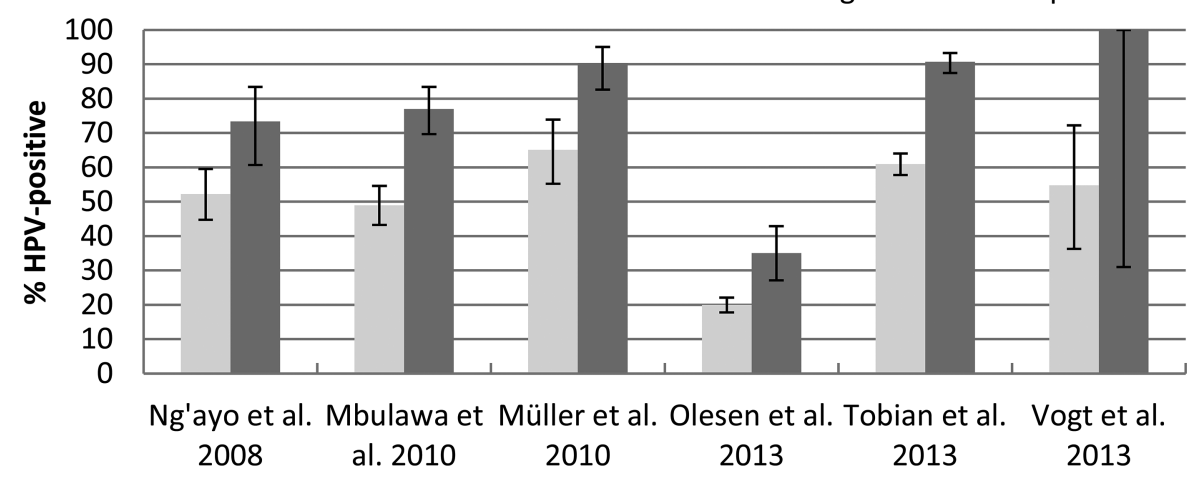

B. HR HPV

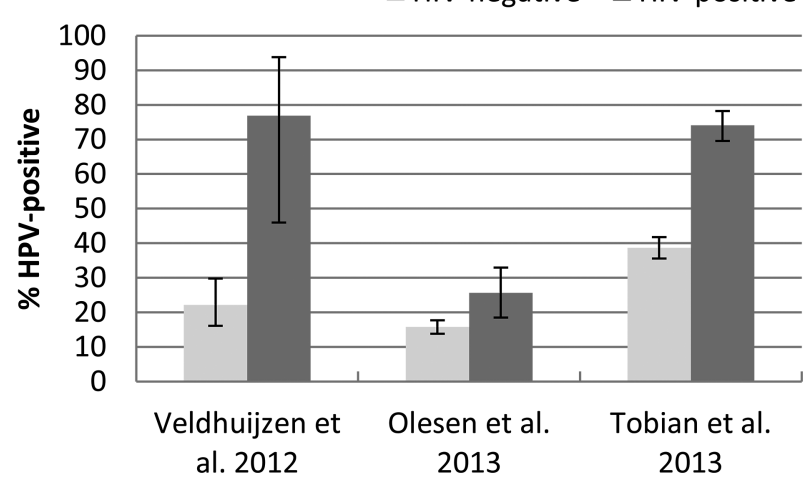

old. ${ }^{20}$ In the studies stratifying by HIV status, Olesen et al reported a flat prevalence curve for any HPV among HIV-negative men (17\%-26\% HPV-positive in all age groups) and an increase in the prevalence of any HPV among HIV-positive men (from $22 \%$ in $25-29$ year olds to $52 \%$ in men $\geq 50$ years old). ${ }^{23}$ Among HIV-negative men, Tobian et al found a HR HPV prevalence of 29\% among 15-19 year olds, then a peak HR HPV prevalence in the age group 20-24 years old $(48 \%)$ and a subsequent decline to $29 \%$ in men $\geq 35$ years old, while among HIV-positive men a more constant and high HR HPV prevalence was seen in all age groups $(71 \%-87 \%)^{24}$ (data not shown).

\section{DISCUSSION}

In this systematic review and meta-analysis, we found that HPV is very common among men in sub-Saharan Africa, the prevalence of any HPV ranging between $19.1 \%$ and $100 \%$. Using random effects meta-analysis, the pooled prevalence of any HPV was $78.2 \%$ among HIV-positive and $49.4 \%$ among HIV-negative men $(\mathrm{p}=0.0632)$. In PCR-based studies, the pooled prevalence of any HPV was $84.5 \%$ among HIV-positive and $56.4 \%$ among HIV-negative men $(\mathrm{p}<0.0001)$. Of the HPV types included in the nine-valent HPV vaccine, the most common HR HPV types were HPV16 and HPV52, and HPV6 was the most common LR HPV type. When examining the prevalence of HPV in relation to age no clear trend was observed.

The worldwide HPV prevalence among men varies widely: in a systematic review, Dunne et al found that the worldwide HPV prevalence ranged between $1.3 \%$ and $72.9 \%$ among men; however, the review excluded immunosuppressed individuals (eg, HIV-positive individuals) and no studies from sub-Saharan Africa were included. ${ }^{9}$ Smith et al reported that the worldwide reported a slight increase in the prevalence $72 \%$ among $18-29$ year olds to $83 \%$ among men $>40$ years 
Table 2 Type-specific prevalence of the HPV types included in the nine-valent HPV vaccine among men in sub-Saharan Africa*

\begin{tabular}{|c|c|c|c|c|c|c|c|c|c|c|c|c|c|c|c|c|c|c|c|c|c|c|}
\hline \multirow[b]{3}{*}{ Authors } & \multirow[b]{3}{*}{$\mathrm{N}$} & \multirow{3}{*}{$\begin{array}{l}\text { Number of } \\
\text { HPV-positive } \\
\text { (any HPV) }\end{array}$} & \multirow{3}{*}{$\begin{array}{l}\text { Number of } \\
\text { HPV-positive } \\
\text { (HR HPV) }\end{array}$} & & \multicolumn{4}{|c|}{ Low-risk HPV types } & \multicolumn{14}{|c|}{ High-risk HPV types } \\
\hline & & & & & \multicolumn{2}{|c|}{ HPV6 } & \multicolumn{2}{|c|}{ HPV11 } & \multicolumn{2}{|c|}{ HPV16 } & \multicolumn{2}{|c|}{ HPV18 } & \multicolumn{2}{|c|}{ HPV31 } & \multicolumn{2}{|c|}{ HPV33 } & \multicolumn{2}{|c|}{ HPV45 } & \multicolumn{2}{|c|}{ HPV52 } & \multicolumn{2}{|c|}{ HPV58 } \\
\hline & & & & & $\mathrm{n}$ & $(\%)$ & $\mathrm{n}$ & $(\%)$ & $\mathrm{n}$ & $(\%)$ & $\mathrm{n}$ & $(\%)$ & $\mathrm{n}$ & $(\%)$ & $\mathrm{n}$ & $(\%)$ & $\mathrm{n}$ & $(\%)$ & $\mathrm{n}$ & $(\%)$ & $\mathrm{n}$ & $(\%)$ \\
\hline \multirow[t]{2}{*}{$\mathrm{Ng}^{\prime}$ ayo et al ${ }^{19}$} & 250 & 144 & 106 & Among all & 24 & (9.6) & 2 & $(0.8)$ & 31 & (12.4) & 17 & (6.8) & 13 & (5.2) & 3 & $(1.2)$ & 7 & (2.8) & 24 & (9.6) & 15 & $(6.0)$ \\
\hline & & & & Among HPV-positive & 24 & (16.7) & 2 & (1.4) & 31 & (21.5) & 17 & (11.8) & 13 & $(9.0)$ & 3 & (2.1) & 7 & (4.9) & 24 & (16.7) & 15 & (10.4) \\
\hline \multirow[t]{2}{*}{ Auvert et $a^{26}$} & 1683 & 321 & 291 & Among all & 183 & (10.9) & 12 & $(0.7)$ & 59 & (3.5) & 52 & (3.1) & 37 & $(2.2)$ & 24 & (1.4) & 35 & (2.1) & 42 & (2.5) & 34 & $(2.0)$ \\
\hline & & & & Among HPV-positive & 183 & (57.0) & 12 & (3.7) & 59 & (18.4) & 52 & (16.2) & 37 & (11.6) & 24 & (7.5) & 35 & $(10.9)$ & 42 & (13.1) & 34 & (10.6) \\
\hline \multirow[t]{2}{*}{ Mbulawa et a $\left.\right|^{13}$} & 471 & 273 & NA & Among all & 24 & (5.1) & 9 & (1.9) & 37 & (7.9) & 20 & $(4.2)$ & 12 & (2.5) & 8 & (1.7) & 33 & $(7.0)$ & 24 & $(5.1)$ & 24 & (5.1) \\
\hline & & & & Among HPV-positive & 24 & (8.8) & 9 & (3.3) & 37 & (13.6) & 20 & (7.3) & 12 & (4.4) & 8 & (2.9) & 33 & (12.1) & 24 & (8.8) & 24 & (8.8) \\
\hline \multirow[t]{2}{*}{ Smith et $a l^{12}$} & 2705 & 1382 & NA & Among all & NA & NA & NA & NA & 265 & $(9.8)$ & 116 & (4.3) & 108 & $(4.0)$ & NA & NA & NA & NA & 127 & (4.7) & NA & NA \\
\hline & & & & Among HPV-positive & NA & NA & NA & NA & 265 & (19.2) & 116 & (8.4) & 108 & $(7.8)$ & NA & NA & NA & NA & 127 & $(9.2)$ & NA & NA \\
\hline \multirow[t]{2}{*}{ Firnhaber et $a^{21}$} & 73 & 73 & 62 & Among all & 31 & (42.5) & 24 & (32.9) & 20 & (27.4) & 11 & (15.1) & 5 & (6.8) & 4 & (5.5) & 12 & (16.4) & 14 & (19.2) & 13 & (17.8) \\
\hline & & & & Among HPV-positive & 31 & (42.5) & 24 & (32.9) & 20 & (27.4) & 11 & (15.1) & 5 & (6.8) & 4 & (5.5) & 12 & (16.4) & 14 & (19.2) & 13 & (17.8) \\
\hline \multirow[t]{2}{*}{ Vardas et $a^{25} \dagger$} & 518 & NA & NA & Among all & 29 & (5.6) & 5 & $(1.0)$ & 23 & (4.4) & 23 & (4.4) & 7 & (1.4) & 8 & (1.6) & 15 & (2.9) & 27 & $(5.2)$ & 18 & (3.5) \\
\hline & & & & Among HPV-positive & NA & NA & NA & NA & NA & NA & NA & NA & NA & NA & NA & NA & NA & NA & NA & NA & NA & NA \\
\hline \multirow{2}{*}{$\begin{array}{l}\text { Veldhuijzen } \\
\text { et } a^{22} \neq\end{array}$} & 166 & NA & 44 & Among all & NA & NA & NA & NA & 7 & $(4.2)$ & 9 & (5.4) & 2 & $(1.2)$ & 4 & (2.4) & 5 & (3.0) & 4 & (2.4) & 6 & (3.6) \\
\hline & & & & Among HPV-positive & NA & NA & NA & NA & 7 & $(15.9)$ & 9 & (20.5) & 2 & (4.5) & 4 & (9.1) & 5 & (11.4) & 4 & (9.1) & 6 & (13.6) \\
\hline \multirow[t]{2}{*}{ Olesen et $a^{23} \S$} & 1813 & 317 & 257 & Among all & 47 & (2.6) & 36 & (2.0) & 47 & (2.6) & 45 & $(2.5)$ & 14 & $(0.8)$ & 5 & $(0.3)$ & 11 & $(0.6)$ & 105 & (5.8) & 9 & $(0.5)$ \\
\hline & & & & Among HPV-positive & 47 & (14.8) & 36 & (11.4) & 47 & (14.8) & 45 & $(14.2)$ & 14 & (4.4) & 5 & (1.6) & 11 & (3.5) & 105 & (33.1) & 9 & (2.8) \\
\hline \multirow[t]{2}{*}{ Tobian et a $\left.\right|^{4}$} & 1399 & 978 & 690 & Among all & 123 & (8.8) & 144 & (10.3) & 160 & (11.4) & 94 & (6.7) & 81 & (5.8) & 72 & (5.1) & 107 & (7.6) & 93 & (6.6) & 132 & (9.4) \\
\hline & & & & Among HPV-positive & 123 & (12.6) & 144 & (14.7) & 160 & (16.4) & 94 & (9.6) & 81 & (8.2) & 72 & (7.4) & 107 & (10.9) & 93 & $(9.5)$ & 132 & (13.5) \\
\hline \multirow[t]{2}{*}{ Vogt et $\left.a\right|^{18}$} & 34 & 20 & 10 & Among all & NA & NA & NA & NA & 4 & (11.8) & NA & NA & NA & NA & NA & NA & NA & NA & NA & NA & NA & NA \\
\hline & & & & Among HPV-positive & NA & NA & NA & NA & 4 & $(20.0)$ & NA & NA & NA & NA & NA & NA & NA & NA & NA & NA & NA & NA \\
\hline
\end{tabular}

*For each study, numbers in bold identify the most frequent HPV type (LR HPV types) or the two most frequent HPV types (HR HPV types).

tFor HPV31 N=513, for HPV33 and HPV58 N=515, for HPV45 N=514, and for HPV52 N=516.

\#Type-specific prevalence among HR HPV-positive men.

Sumber of HPV-positive with a result from the LiPA test ( $n=317$ for any HPV and $n=257$ for HR HPV).

$H P V$, human papillomavirus; HR, high-risk; LR, low-risk; NA, not available. 


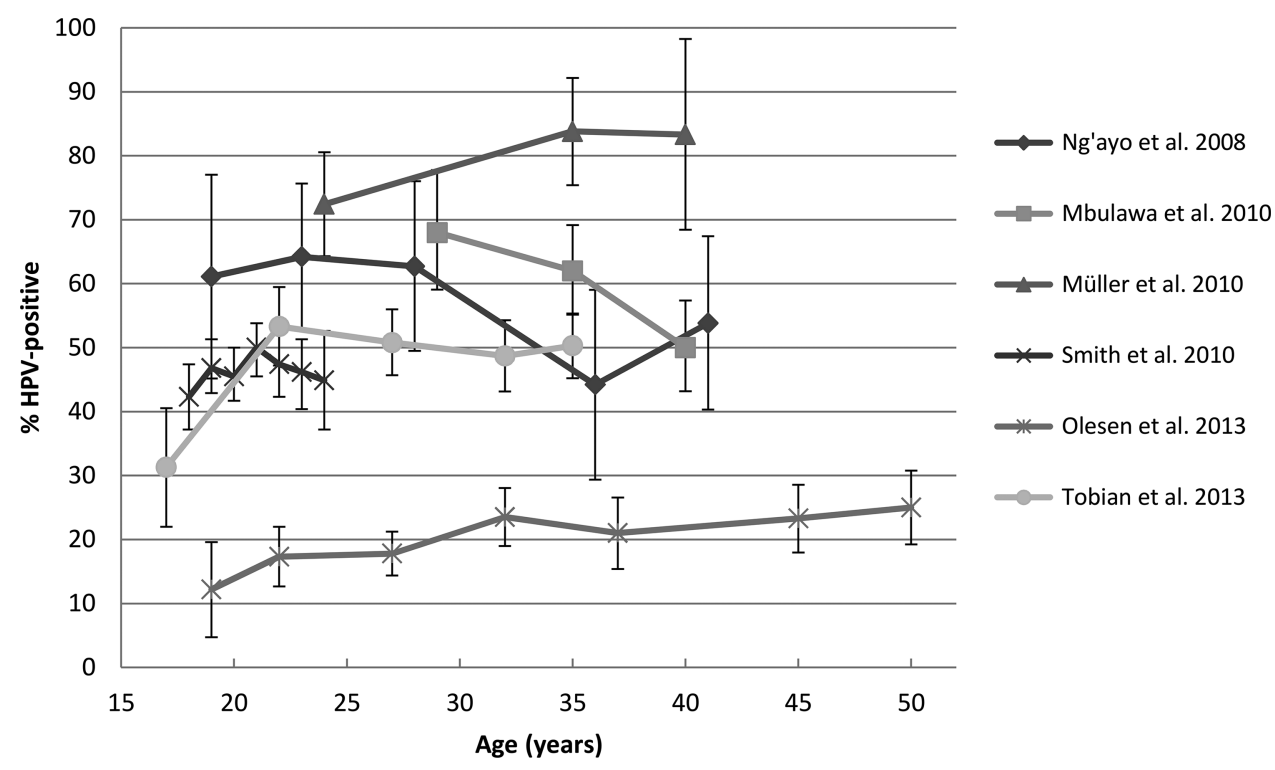

Figure 2 Overall age-specific prevalence of any and/or high-risk human papillomavirus (HR HPV) and 95\% Cls among men in sub-Saharan Africa* $, \uparrow, \ddagger, \S$. *When estimates were presented for an age group, the mean of the age range was used for graphical presentation of data points; tFor Tobian et $a^{24}$ the age-specific prevalence of HR HPV is shown, while for all other studies the age-specific prevalence of any HPV is shown; fFor Smith et $\mathrm{al}^{12}$ the estimates presented for the glans specimen were used; $\S$ Please see online supplementary table S3 for the exact numbers used in the graph.

HPV prevalence ranged from $2 \%$ to $93 \%$ among high-risk men (STI clinic attendees, HIV-positive men, etc) and from $1 \%$ to $84 \%$ among low-risk men (all other men). ${ }^{8}$ Vardas et al reported that the overall HPV prevalence was $21.2 \%$ among men from five continents with the highest HPV prevalence among men in Africa and lowest in the Asia-Pacific region, which was exemplified by the HPV16 prevalence data (Africa $4.4 \%$ vs Asia-Pacific region $0.8 \%){ }^{25}$

The differences in HPV prevalence across populations could reflect differences in sexual behaviour. In the literature on HIV infection it is discussed that the particularly high HIV infection rates seen in some African populations could be explained by a higher prevalence of concurrent sexual partnerships. ${ }^{27} 28$ Similar to the spread of HIV infection, many concurrent sexual partnerships may increase the risk of acquiring HPV and transmitting HPV infection. Other risk factors known to be associated with HPV could explain differences in HPV prevalence across populations, for example, male circumcision, a high number of sexual partners and sexual contact with prostitutes. Furthermore, the high prevalence of HIV and other sexually transmitted infections could increase the occurrence of HPV infection.

Among women, Bruni et al found that the estimated global HPV prevalence is $12 \%^{29}$ with a higher HPV prevalence in developing countries than in developed countries. The HPV prevalence among women in sub-Saharan Africa is approximately 24\% and, in particular, a high HPV prevalence is observed in Eastern Africa (34\%). ${ }^{29}$ A high HPV prevalence is thus observed both among men and women in sub-Saharan Africa. The meta-analysis by Bruni et al was restricted to HIV-negative women with normal cytological findings, which may account for the higher HPV prevalence observed among men than among women.

We found that the pooled prevalence of any HPV was higher among HIV-positive than among HIV-negative men and in PCR-based studies, this difference was statistically significant. Generally, PCR-based methods are more sensitive ${ }^{11}$ than non-PCR-based methods and a higher HPV prevalence is to be expected. The higher prevalence of HPV among HIV-positive men may be due to immune suppression, which can lead to increased acquisition of HPV infections. Moreover, HIV-positive men have been found to have a significantly lower rate of clearance of HR HPV infections than HIV-negative men. ${ }^{30}$ It has also been suggested that HIV infection may increase reactivation of latent HPV infections and also leads to a higher degree of persistent infections. ${ }^{31}$ With increased acquisition, reduced clearance of HPV and increased persistence of HPV infections, HIV-positive individuals may be at an increased risk of developing cancer and precancerous lesions. Recent studies have also suggested that HPV infection may increase the risk of acquisition of HIV infection. ${ }^{32}$

Although based on few studies, the prevalence of HPV appeared to be higher among uncircumcised than among circumcised men. This is in line with a recent meta-analysis demonstrating that circumcised men were less likely to have prevalent genital HPV infection than uncircumcised men (pooled OR $=0.57 ; 95 \%$ CI 0.45 to 0.71 ). ${ }^{33}$ Similarly, RCTs conducted in sub-Saharan Africa demonstrated that male circumcision reduced the prevalence of penile HR HPV infection among HIV-negative and HIV-positive men, ${ }^{34-36}$ reduced the acquisition of new HR HPV infections and increased clearance of pre-existing HR HPV infection in HIV-negative men. ${ }^{37}$ The proposed biological mechanisms for this association is that the keratinised skin surface and scar formation after male circumcision reduces viral access to the basal epidermal cells which are target cells for HPV infection. ${ }^{38}$ Furthermore, the moist environment under the foreskin in uncircumcised men may increase HPV viral persistence. ${ }^{39}$

Of the HPV types included in the nine-valent HPV vaccine, the two most common HR HPV types were HPV16 and HPV52, and HPV6 was the most common LR HPV type. Studies conducted among men in other parts of the world, for example, in Europe, have similarly reported HPV16 as being the most common HR HPV type among men. ${ }^{25} 40-42$ HPV52 is often reported as being particularly frequent in sub-Saharan Africa; for example, the meta-analysis by Bruni et $a l^{29}$ of the HPV prevalence among women worldwide showed that HPV52 was more common in Africa (2.4\%) than in Europe $(0.4 \%)$. HPV52 belongs to the $\alpha 9$ species group, together with HPV16, 
and is thus considered an important HR HPV type in carcinogenesis to humans. ${ }^{43}$ Nonetheless, HPV16 and HPV18 account for the largest number of HPV-related cancers worldwide as these are the most common HR HPV types in penile cancer and cervical cancer, ${ }^{4}$ and in head-and-neck-cancer. ${ }^{6}$

There was no clear trend in the age-specific HPV prevalence among men in sub-Saharan Africa, although there was a tendency towards a relatively flat age-specific HPV prevalence curve as also reported in some studies from other parts of the world. ${ }^{8}$ In contrast, among women the HPV prevalence often peaks in the younger age groups followed by a decline. ${ }^{29} 44$ In some studies, a second peak in older women has been observed, in particular in populations in South America and in some parts of Africa. ${ }^{29} 45$ The relatively flat age-specific prevalence curve observed in men may reflect differences in the natural history of HPV among men and women or differences in exposure to HPV infection. HPV infections may be less likely to persist in men than in women possibly due to differences in the epithelial lining of the penis and the cervix and, therefore, the observed HPV prevalence among men may reflect the continued acquisition of new infections rather than persistent infections.

The strength of the study is the thorough literature search aiming at identifying all studies reporting data on HPV DNA prevalence among men in sub-Saharan Africa. A limitation of the study is that due to a relative low number of included studies, the pooled prevalence estimates are more prone to the variation between the studies which is also reflected in the tests for heterogeneity. A further limitation is that due to a large degree of heterogeneity, no overall pooled HPV prevalence for all studies was calculated; instead, we calculated pooled HPV prevalence for different subgroups. Furthermore, for most studies, the age-specific HPV prevalence was not stratified by HIV status and therefore the overall age-specific HPV prevalence is presented. In addition, not all studies had information on the type-specific prevalence of the HPV types included in the nine-valent HPV vaccine.

In conclusion, we conducted a systematic review and meta-analysis to examine the HPV prevalence among men in sub-Saharan Africa. The HPV prevalence varied substantially between studies. The pooled prevalence of any HPV was higher among HIV-positive than HIV-negative men, in particular in PCR-based studies. The most common HR HPV types were HPV16 and HPV52, and HPV6 was the most common LR HPV type. These estimates show that the burden of HPV infection is high among men in sub-Saharan Africa, which together with the lack of effective screening programmes could explain the high rates of penile and cervical cancer in this part of the world. Implementation of the prophylactic HPV vaccines could potentially prevent this large burden of HPV in sub-Saharan Africa.

\section{Key messages}

- We performed a systematic review and meta-analysis to summarise the available data on the human papillomavirus (HPV) prevalence among men in sub-Saharan Africa.

- The prevalence of any HPV ranged widely from $19.1 \%$ to $100 \%$ among men in sub-Saharan Africa.

- In PCR-based studies, the pooled prevalence of any HPV was $84.5 \%$ (95\% Cl 74.2 to 91.2$)$ among HIV-positive and $56.4 \%(95 \% \mathrm{Cl} 49.7$ to 62.9$)$ among HIV-negative men $(p<0.0001)$.

- The most common high-risk HPV types were HPV16 and HPV52, and HPV6 was the most common low-risk HPV type.

\section{Handling editor Jackie A Cassell}

Contributors TBO and CM conducted the systematic review and extracted the data. JC and KKA conducted the statistical analyses. TBO drafted the article. All authors contributed, read and approved the final manuscript. TBO, CM and SKK had full access to all the data in the study and had final responsibility for the decision to submit for publication.

Competing interests SKK received lecture fees, advisory board fees and unrestricted research grants through her institution from Merck and Sanofi Pasteur MSD. CM received lecture fees and support for conference participation from Sanofi Pasteur MSD. The remaining authors declare no conflicts of interest.

Provenance and peer review Not commissioned; externally peer reviewed.

\section{REFERENCES}

1 IARC. IARC Monographs on the Evaluation of Carcinogenic Risks to Humans. Lyon, France: Volume 90: Human Papillomaviruses, 2007

2 Parkin DM, Bray F. Chapter 2: The burden of HPV-related cancers. Vaccine 2006;24 (Suppl 3):S3-11-/25.

3 Munoz N, Bosch FX, de SS, et al. Epidemiologic classification of human papillomavirus types associated with cervical cancer. N Engl J Med 2003;348:518-27

4 Miralles-Guri C, Bruni L, Cubilla AL, et al. Human papillomavirus prevalence and type distribution in penile carcinoma. J Clin Pathol 2009;62:870-8.

5 Munoz N, Bosch FX, Castellsague X, et al. Against which human papillomavirus types shall we vaccinate and screen? The international perspective. Int I Cancer 2004;111:278-85.

6 Kreimer AR, Clifford GM, Boyle P, et al. Human papillomavirus types in head and neck squamous cell carcinomas worldwide: a systematic review. Cancer Epidemiol Biomarkers Prev 2005;14:467-75.

7 Schiller JT, Castellsague X, Garland SM. A review of clinical trials of human papillomavirus prophylactic vaccines. Vaccine 2012;30(Suppl 5):F123-38.

8 Smith JS, Gilbert PA, Melendy A, et al. Age-specific prevalence of human papillomavirus infection in males: a global review. J Adolesc Health 2011;48:540-52.

9 Dunne EF, Nielson CM, Stone KM, et al. Prevalence of HPV infection among men: A systematic review of the literature. J Infect Dis 2006;194:1044-57.

10 Moher D, Liberati A, Tetzlaff J, et al. Preferred reporting items for systematic reviews and meta-analyses: the PRISMA statement. PLoS Med 2009;6:e1000097.

11 Iftner T, Villa LL. Chapter 12: Human papillomavirus technologies. J Nat/ Cancer Inst Monogr 2003;80-8.

12 Smith JS, Backes DM, Hudgens MG, et al. Prevalence and risk factors of human papillomavirus infection by penile site in uncircumcised Kenyan men. Int I Cancer 2010;126:572-7.

13 Mbulawa ZZ, Marais DJ, Johnson LF, et al. Influence of human immunodeficiency virus and CD4 count on the prevalence of human papillomavirus in heterosexual couples. J Gen Virol 2010;91:3023-31.

14 United Nations Statistics Division. Composition of macro geographical (continental) regions, geographical sub-rehions, and selected economic and other groupings. New York. Accessed 13-3-2014.

15 Cochrane Handbook for Systematic Reviews of Interventions: Cochrane Book Series. The Cochrane Collaboration, 2008

16 Higgins JP, Thompson SG, Deeks JJ, et al. Measuring inconsistency in meta-analyses. BMJ 2003:327:557-60.

17 R: A Language and Environment for Statistical Computing, R Core Team, R Foundation for Statistical Computing. 2013. Vienna, Austria.

18 Vogt SL, Gravitt PE, Martinson NA, et al. Concordant Oral-Genital HPV Infection in South Africa Couples: Evidence for Transmission. Front Oncol 2013;3:303.

19 Ng'ayo MO, Bukusi E, Rowhani-Rahbar A, et al. Epidemiology of human papillomavirus infection among fishermen along Lake Victoria Shore in the Kisumu District, Kenya. Sex Transm Infect 2008;84:62-6.

20 Müller EE, Chirwa TF, Lewis DA. Human papillomavirus (HPV) infection in heterosexual South African men attending sexual health services: associations between HPV and HIV serostatus. Sex Transm Infect 2010;86:175-80.

21 Firnhaber C, Sello M, Maskew M, et al. Human papillomavirus types in HIV seropositive men with penile warts in Johannesburg, South Africa. Int I STD AIDS 2011:22:107-9.

22 Veldhuijzen NJ, Dhont N, Vyankandondera J, et al. Prevalence and concordance of HPV, HIV, and HSV-2 in heterosexual couples in Kigali, Rwanda. Sex Transm Dis 2012;39:128-35

23 Olesen TB, Iftner T, Mwaiselage J, et al. Prevalence and Type-Distribution of Human Papillomavirus among 1,813 Men in Tanzania and the Relationship to HIV Status. Sex Transm Dis 2013;40:592-8

24 Tobian AA, Grabowski MK, Kigozi G, et al. High-risk human papillomavirus prevalence is associated with HIV infection among heterosexual men in Rakai, Uganda. Sex Transm Infect 2013:89:122-7. 
25 Vardas E, Giuliano AR, Goldstone $S$, et al. External genital human papillomavirus prevalence and associated factors among heterosexual men on 5 continents. J Infect Dis 2011;203:58-65.

26 Auvert B, Lissouba P, Cutler $E$, et al. Association of oncogenic and nononcogenic human papillomavirus with HIV incidence. J Acquir Immune Defic Syndr 2010;53:111-16

27 Westercamp N, Mattson CL, Bailey RC. Measuring Prevalence and Correlates of Concurrent Sexual Partnerships Among Young Sexually Active Men in Kisumu, Kenya. AIDS Behav 2013;17:3124-32.

28 Morris M, Epstein $\mathrm{H}$, Wawer M. Timing is everything: international variations in historical sexual partnership concurrency and HIV prevalence. PLoS One 2010;5: e14092.

29 Bruni L, Diaz M, Castellsague $X$, et al. Cervical human papillomavirus prevalence in 5 continents: meta-analysis of 1 million women with normal cytological findings. J Infect Dis 2010;202:1789-99.

30 Tobian AA, Kigozi G, Gravitt PE, et al. Human papillomavirus incidence and clearance among HIV-positive and HIV-negative men in sub-Saharan Africa. AIDS 2012;26:1555-65.

31 Gravitt PE. The known unknowns of HPV natural history. J Clin Invest 2011;121:4593-9.

32 Houlihan CF, Larke NL, Watson-Jones D, et al. Human papillomavirus infection and increased risk of HIV acquisition. A systematic review and meta-analysis. AIDS 2012;26:2211-22.

33 Larke N, Thomas SL, Dos SSI, et al. Male circumcision and human papillomavirus infection in men: a systematic review and meta-analysis. J Infect Dis 2011;204:1375-90.

34 Tobian AA, Serwadda D, Quinn TC, et al. Male circumcision for the prevention of HSV-2 and HPV infections and syphilis. N Engl J Med 2009;360:1298-309.
35 Serwadda D, Wawer MJ, Makumbi F, et al. Circumcision of HIV-infected men: effects on high-risk human papillomavirus infections in a randomized trial in Rakai, Uganda. J Infect Dis 2010:201:1463-9.

36 Auvert B, Sobngwi-Tambekou J, Cutler E, et al. Effect of male circumcision on the prevalence of high-risk human papillomavirus in young men: results of a randomized controlled trial conducted in Orange Farm, South Africa. J Infect Dis 2009;199:14-9.

37 Gray RH, Serwadda D, Kong $X$, et al. Male circumcision decreases acquisition and increases clearance of high-risk human papillomavirus in HIV-negative men: a randomized trial in Rakai, Uganda. J Infect Dis 2010;201:1455-62.

38 Szabo R, Short RV. How does male circumcision protect against HIV infection? BMJ 2000;320:1592-4.

39 Liu CM, Hungate BA, Tobian AA, et al. Male circumcision significantly reduces prevalence and load of genital anaerobic bacteria. MBio 2013;4:e00076.

40 Jalal $\mathrm{H}$, Stephen $\mathrm{H}$, Bibby DF, et al. Molecular epidemiology of genital human papillomavirus and Chlamydia trachomatis among patients attending a genitourinary medicine clinic-will vaccines protect? Int J STD AIDS 2007;18:617-21.

41 Barzon L, Militello V, Pagni S, et al. Distribution of human papillomavirus types in the anogenital tract of females and males. J Med Virol 2010;82:1424-30.

42 Vriend HJ, Bogaards JA, van der Klis FR, et al. Patterns of human papillomavirus DNA and antibody positivity in young males and females, suggesting a site-specific natural course of infection. PLoS One 2013;8:e60696.

43 de Villiers EM, Fauquet C, Broker TR, et al. Classification of papillomaviruses. Virology 2004:324:17-27.

44 Schiffman M, Castle PE, Jeronimo J, et al. Human papillomavirus and cervical cancer. Lancet 2007:370:890-907.

45 Dartell M, Rasch V, Kahesa C, et al. Human papillomavirus prevalence and type distribution in 3603 HIV-positive and HIV-negative women in the general population of Tanzania: the PROTECT study. Sex Transm Dis 2012;39:201-8. 